\title{
Modulation of oxygen production in Archaean oceans by episodes of $\mathrm{Fe}(\mathrm{II})$ toxicity
}

\author{
Elizabeth D. Swanner ${ }^{1 \star}$, Aleksandra M. Mloszewska², Olaf A. Cirpka', Ronny Schoenberg${ }^{1}$, \\ Kurt O. Konhauser ${ }^{2}$ and Andreas Kappler ${ }^{1}$
}

\begin{abstract}
Oxygen accumulated in the surface waters of the Earth's oceans $^{1}$ and atmosphere ${ }^{2}$ several hundred million years before the Great Oxidation Event between 2.4 and 2.3 billion years ago $^{3}$. Before the Great Oxidation Event, periods of enhanced submarine volcanism associated with mantle plume events ${ }^{4}$ supplied Fe(II) to sea water. These periods generally coincide with the disappearance of indicators of the presence of molecular oxygen in Archaean sedimentary records ${ }^{5}$. The presence of $\mathrm{Fe}(\mathrm{II})$ in the water column can lead to oxidative stress in some organisms as a result of reactions between $\mathrm{Fe}$ (II) and oxygen that produce reactive oxygen species ${ }^{6}$. Here we test the hypothesis that the upwelling of Fe(II)-rich, anoxic water into the photic zone during the late Archaean subjected oxygenic phototrophic bacteria to Fe(II) toxicity. In laboratory experiments, we found that supplying Fe(II) to the anoxic growth medium housing a common species of planktonic cyanobacteria decreased both the efficiency of oxygenic photosynthesis and their growth rates. We suggest that this occurs because of increasing intracellular concentrations of reactive oxygen species. We use geochemical modelling to show that Fe(II) toxicity in conditions found in the late Archaean photic zone could have substantially inhibited water column oxygen production, thus decreasing fluxes of oxygen to the atmosphere. We therefore propose that the timing of atmospheric oxygenation was controlled by the timing of submarine, plumetype volcanism, with Fe(II) toxicity as the modulating factor.
\end{abstract}

Possible biological explanations for the slow tempo of atmospheric oxidation invoke limitations on the efficiency of early oxygenic photosynthesis, such as the toxicity of oxygen to the organisms who first produced it ${ }^{7}$, or that a paucity of key nutrients limited growth of oxygenic phototrophs in late Archaean sea water ${ }^{8}$. Iron is a key limiting nutrient for oxygenic photosynthesis in modern, oxic oceans, and enhanced Fe fluxes to the surface ocean are generally thought to have increased primary productivity over geologic time ${ }^{9}$. Coastal environments in the late Archaean experienced enhanced fluxes of $\mathrm{Fe}$ in its reduced, soluble form $(\mathrm{Fe}(\mathrm{II}))$ from upwelling sea water saturated with $\mathrm{Fe}(\mathrm{II})$ supplied from hydrothermal leaching of oceanic crust ${ }^{10,11}$. In the absence of land plants in the late Archaean, a reasonable assumption is that most oxygen was produced or built up locally in coastal marine environments that experienced such upwelling ${ }^{5,12}$, and oxygenic phototrophs would have experienced these Fe(II) fluxes. Nearly half of Earth's primary productivity, and hence its oxygen production, is today produced in the oceans ${ }^{13}$, and planktonic marine cyanobacteria, such as Synechococcus and Prochlorococcus, account for up to $25 \%$ of this number ${ }^{14}$. As previous work documented significant oxidative stress when planktonic cyanobacteria were exposed to just $10 \mu \mathrm{M} \mathrm{Fe}$ (II) (ref. 6), an important constraint on late Archaean oxygen production is the fitness of planktonic cyanobacteria in producing oxygen in the presence of elevated $\mathrm{Fe}$ (II) fluxes.

We therefore used the planktonic marine cyanobacterium Synechococcus PCC 7002 to examine the effects of Fe(II) on oxygenic photosynthesis (see Supplementary Information for justification on use of this strain). We documented growth for this strain on anoxic medium supplied with different initial concentrations of $\mathrm{Fe}(\mathrm{II})$ (Fig. 1a). As oxygen was produced during growth, $\mathrm{Fe}$ (II) concentrations dropped owing to oxidation, and similar cell densities were ultimately achieved despite differing initial Fe(II) concentrations. However, the growth rates $\left(\mu ; \mathrm{d}^{-1}\right)$ calculated from the initial part of the growth curves in Fig. 1a, when $\mathrm{Fe}(\mathrm{II})$ was still present in the medium, dropped significantly as initial $\mathrm{Fe}(\mathrm{II})$ concentrations increased to $180 \mu \mathrm{M}$ and higher (Fig. 1b). Correspondingly, oxygen production was suppressed in cells grown at $300 \mu \mathrm{M} \mathrm{Fe}$ (II) or higher initial Fe(II) concentrations, evidenced by a significantly lower actinic yield, the ratio of variable fluorescence relative to maximum fluorescence $\left(F_{\mathrm{v}} / F_{\mathrm{m}}\right.$; ref. 15 ; Fig. 1d; for additional justification see Supplementary Information and Supplementary Fig. 1). An increase in Fe(II) concentrations from 10 to $100 \mu \mathrm{M}$ in light-incubated cell suspensions caused intracellular reactive oxygen species (ROS) levels to double, and ROS levels quadrupled in the presence of $1,000 \mu \mathrm{M} \mathrm{Fe}(\mathrm{II})$ (Fig. 1c). These results link Fe(II) toxicity to enhanced intracellular concentrations of ROS, which results in a decrease in the efficiency of oxygenic photosynthesis, possibly due to inhibited repair of damaged photosystems ${ }^{16}$, and decreased growth rates.

To infer whether the $\mathrm{Fe}(\mathrm{II})$ toxicity we observed with Synechococcus PCC 7002 is common to diverse cyanobacteria, we screened microbial ecology data sets of circumneutral $\mathrm{pH}$ springs with persistent Fe(II) fluxes into sunlit, oxygenated surface environments (Table 1). All springs in which cyanobacteria were reported have less than $80 \mu \mathrm{M} F$ (II) in source waters or within microbial mats. Springs with higher Fe(II) concentrations, in the range of several hundred $\mu \mathrm{M} \mathrm{Fe}(\mathrm{II})$, are instead dominated by microaerophilic Fe(II)-oxidizers. The range of Fe(II) concentrations in which cyanobacteria inhabit these Fe(II)-rich environments is within the range of $7.5-55 \mu \mathrm{M} F($ II) at which we observed robust growth (Fig. 1a). The significant increase in intracellular ROS concentrations that we observed at $100 \mu \mathrm{M}$ Fe(II) (Fig. 1c), the colonization of natural cyanobacteria in $\mathrm{Fe}$ (II)-rich springs with less than $80 \mu \mathrm{M} \mathrm{Fe}(\mathrm{II})$ (Table 1), and previous reports of Fe(II) toxicity for lagoonal cyanobacteria between 50 and $203 \mu \mathrm{M} \mathrm{Fe(II)} \mathrm{(ref.} \mathrm{17)}$ lead us to propose that $\mathrm{Fe}(\mathrm{II})$ toxicity is common to cyanobacteria in the range of tens to hundreds of micromolar.

${ }^{1}$ Department of Geosciences, University of Tübingen, Tübingen 72076, Germany. ${ }^{2}$ Department of Earth and Atmospheric Sciences, University of Alberta, Edmonton, Alberta T6G 2E3, Canada. *e-mail: elizabeth.swanner@ifg.uni-tuebingen.de 

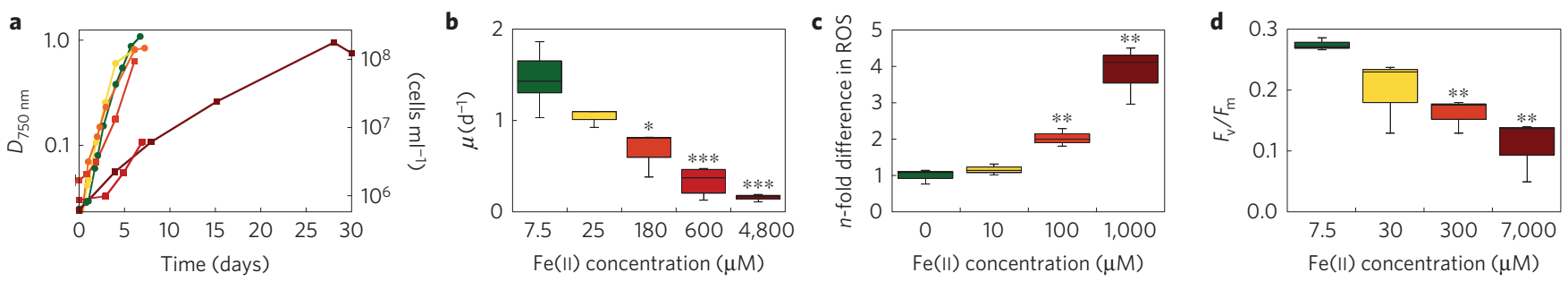

Figure 1 | Evidence for Fe(II) toxicity in Synechococcus PCC 7002. a, Attenuance ( $D_{750}$ nm; circles) of cells grown in the presence of $7.5 \mu M$ (green), $25 \mu M$ (yellow), or $55 \mu \mathrm{M}$ (orange) Fe(II). Direct counts (squares), on a scale equivalent to the attenuance axis, of cells grown with $180 \mu \mathrm{M}$ (dark orange), $600 \mu \mathrm{M}$ (red) or 4,800 $\mu \mathrm{M}$ (brown) Fe(II). Standard error is generally smaller than the symbols. b, Cell-specific growth rates calculated from a, their biological replicates, and additional experiments. $\mathbf{c}$, Intracellular ROS concentrations of cell suspensions incubated with Fe(II) in light. $\mathbf{d}$, Actinic yield $\left(F_{\mathrm{v}} / F_{\mathrm{m}}\right)$ of cells grown at different initial $\mathrm{Fe}(\mathrm{II})$ concentrations. Squares in $\mathbf{b}$-d define the 25th and 75th quartile, horizontal lines the median, and the extending bars the minimum and maximum values of biological replicates. Asterisks denote the statistical significance: ${ }^{*}$ for $P<0.05$ (significant), ${ }^{* *}$ for $P<0.01$ (very significant), and ${ }^{* * *}$ for $P<0.001$ (extremely significant). No asterisk indicates that differences are not statistically significant.
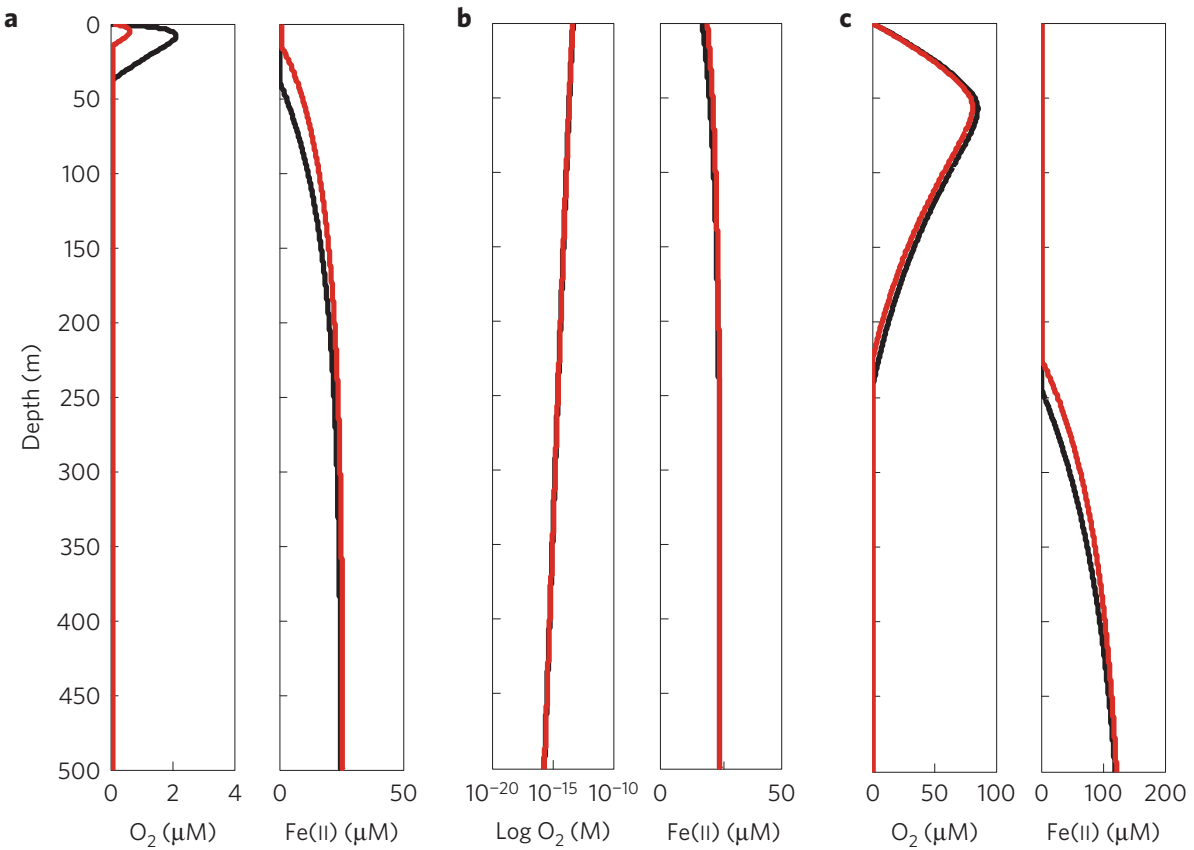

Figure 2 | Model of oxygen production modulated by Fe(II) toxicity. a, With deepwater Fe(II) concentrations of $25 \mu \mathrm{M}$ and an upwelling rate of $95 \mathrm{~m}$ yr ${ }^{-1}$, Fe(II) toxicity (red lines) reduces photosynthetic oxygen production so fluxes of oxygen to the atmosphere are only $36 \%$ of a scenario with no Fe(II) toxicity (black lines). b. With an enhanced upwelling rate $\left(473 \mathrm{~m} \mathrm{yr}^{-1}\right)$, high Fe(II) fluxes consume oxygen, resulting in negligible oxygen release to the atmosphere. c, Using an average global upwelling rate $\left(4 \mathrm{~m} \mathrm{yr}^{-1}\right)$, the Fe(II) flux cannot buffer oxygen release, either through chemical reaction or Fe(II) toxicity, even with enhanced deepwater Fe(II) concentrations (120 $\mu \mathrm{M})$.

If $\mathrm{Fe}(\mathrm{II})$ is toxic to modern cyanobacteria, despite diverse strategies to detoxify ROS (ref. 6), it is possible that early cyanobacteria, or the organisms carrying out oxygenic photosynthesis during the late Archaean, also experienced Fe(II) toxicity, particularly if they had not yet acquired ROS detoxification mechanisms ${ }^{7}$. We therefore used a steady-state advective-diffusive transport model to address: whether $\mathrm{Fe}(\mathrm{II})$ would have reached the photic zone at 'oxygen oases' along upwelling zones; and the effect of $\mathrm{Fe}(\mathrm{II})$ toxicity on photosynthetic oxygen release and oxygen fluxes from the ocean to the atmosphere. The model allows Fe(II) to upwell from a deep basin and react with oxygen produced in the photic zone by oxygenic photosynthesis. Using an upwelling rate of $95 \mathrm{~m} \mathrm{yr}^{-1}$ (ref. 18), and $\mathrm{Fe}$ (II) concentrations of $25 \mu \mathrm{M}$ at depth in a $500 \mathrm{~m}$ basin, dissolved oxygen in surface waters reaches a maximum of $2 \mu \mathrm{M}$ (Fig. 2a), similar to previously modelled values in Archaean 'oxygen oases' along upwelling zones ${ }^{12}$ (see Supplementary Information for justification of parameters). However, when an inhibition parameter fit from the $F_{\mathrm{v}} / F_{\mathrm{m}}$ data in Fig. 1d was invoked to simulate the effect of Fe(II) toxicity, the rate of photosynthetic oxygen release was reduced to $80 \%$, and the flux of oxygen to the atmosphere decreased to only $36 \%$ of values in the uninhibited scenario. Using higher estimates for deepwater $\mathrm{Fe}$ (II) concentrations, the effects of $\mathrm{Fe}$ (II) toxicity on oxygen release become more pronounced (Supplementary Fig. 2). In the model, enhanced upwelling rates $\left(473 \mathrm{~m} \mathrm{yr}^{-1} ;\right.$ ref. 18$)$, led to diminished oxygen production (Fig. 2b), and negligible fluxes of oxygen to the atmosphere $\left(<10^{-17} \mathrm{M} \mathrm{m}^{2} \mathrm{~s}^{-1}\right)$. In this scenario, the enhanced reductant (that is, $\mathrm{Fe}(\mathrm{II})$ ) flux, which consumes most oxygen produced, becomes more important than $\mathrm{Fe}(\mathrm{II})$ toxicity in modulating oxygen release. There is little effect of $\mathrm{Fe}(\mathrm{II})$ toxicity on photosynthetic oxygen production or release of oxygen to the atmosphere at average global upwelling rates $\left(4 \mathrm{~m} \mathrm{yr}^{-1}\right)$, as oxygen produced in the photic zone effectively buffers the much lower flux of $\mathrm{Fe}(\mathrm{II})$ from entering surface waters (Fig. 2c). In such a scenario, more analogous to an open-ocean setting, concentrations of tens of micromolar dissolved oxygen are achieved, implicating such sites as potential late Archaean 'oxygen oases' rather than previously 
Table 1 | Microbial ecology of circumneutral pH, Fe(II)-rich springs or seeps.

\begin{tabular}{|c|c|c|c|}
\hline Site type & Maximum dissolved Fe(II) & Cyanobacteria detected? Method? & Reference \\
\hline Cold spring, Iceland & $<1.7 \mu \mathrm{M}$ & Yes. Molecular. & Ref. 30 \\
\hline Fuschna cold spring, Switzerland & $16 \mu \mathrm{M}$ & Yes. Molecular. & Ref. 31 \\
\hline Groundwater seep, Ohyato Park, Tokyo, Japan & $37.6 \mu \mathrm{M}$ & No. Molecular. & Ref. 32 \\
\hline Spring feeding Ogilvie Creek, Ontario, Canada & $50 \mu \mathrm{M}$ & Yes. Microscopy. & Ref. 33 \\
\hline Sambe hot spring, Shimane Prefecture, Japan & $30-60 \mu \mathrm{M}$ (total Fe) & Yes. Molecular. & Ref. 34 \\
\hline Chocolate Pots hot spring, Yellowstone NP, USA & $\begin{array}{l}50-200 \mu \mathrm{M} \text { at source; } \\
50-80 \mu \mathrm{M} \text { within cyanobacterial mats }\end{array}$ & Yes. Microscopy. & $\begin{array}{l}\text { Ref. 35; } \\
\text { Ref. } 36\end{array}$ \\
\hline Seep to Chalk River, Ontario, Canada & $60-112 \mu \mathrm{M}$ & No. Molecular. & Ref. 37 \\
\hline Seep to West Berry Creek, California, USA & $156 \mu \mathrm{M}($ total Fe) & No. Molecular. & Ref. 38 \\
\hline Springs, Virginia, USA & $127-177 \mu \mathrm{M} ; 12.5-48.2 \mu \mathrm{M}$ & No. Microscopy. & Ref. 39 \\
\hline Seeps to Contrary Creek, Virginia, USA & $171 \mu \mathrm{M}$ and $235 \mu \mathrm{M}$ & Reportedly at low numbers. & Ref. 40 \\
\hline Seep, Aarhus, Denmark & $250 \mu \mathrm{M}$ & No. Microscopy. & Ref. 41 \\
\hline Jackson Creek, Indiana, USA & $320-450 \mu \mathrm{M}$ & No. Molecular. & Ref. 42 \\
\hline
\end{tabular}

assumed coastal settings with higher upwelling rates. A caveat of this result is that nutrient limitation in such settings may have limited their productivity, and our model does not account for these limitations.

On the basis of experimental and ecological evidence for Fe(II) toxicity in cyanobacteria and the low oxygen fluxes modelled for periods of $\mathrm{Fe}(\mathrm{II})$ upwelling, we propose that plume-driven submarine volcanism and associated changes in sea level, circulation and deepwater reductant fluxes could have modulated late Archaean oxygen production. Numerous studies implicate episodic inputs of oxygen or a gradual rise of oxygen in the atmosphere and surface ocean before the Great Oxidation Event ${ }^{1,2,19,20}$ (GOE). Geochemical indicators, lasting perhaps tens of millions of years ${ }^{21}$, signal the periodic presence of dissolved oxygen in sea water along the slope of the Campbellrand/Malmani platform in South Africa between 2.7 and 2.5 billion years ago $(\mathrm{Ga})$. During this interval, shifts towards heavier $\delta^{15} \mathrm{~N}$ values in shale organic carbon are consistent with onset of an oxic nitrogen cycle ${ }^{22}$, and contemporaneous shifts in sulphur isotopes indicating an oxidative sulphur cycle occur in coeval sediments in the Mount McRae shale in present-day northern Australia ${ }^{23}$. Together with varying abundances of rhenium and molybdenum and $\mathrm{Fe}$ speciation data from shales that reflect cycling of these elements in bottom waters with some oxygen ${ }^{5}$, and coupled iron-molybdenum isotopic evidence for formation of $\mathrm{Fe}$ (III) (oxyhydr)oxide minerals in the water column ${ }^{24}$, these indicators implicate oxygen production in pre-GOE coastal settings of the Transvaal and Hamersley basins.

In contrast, geochemical indicators for an oxygenated water column disappear from the Campbellrand/Malmani platform during major sea-level transgressions in which in $\mathrm{Fe}$ (II)-rich sea water blanketed the platform, slope and basin in iron formations ${ }^{10,21}$. These shifts from carbonate to iron formation deposition are temporally linked to plume-driven submarine volcanism ${ }^{10,25}$, which coincides with enhanced upwelling of $\mathrm{Fe}$ (II)-rich waters ${ }^{10}$. The main source of $\mathrm{Fe}$ (II) to late Archaean sea water is thought to have been upwelling hydrothermal fluids derived from oceanic crust altered at high temperature $\left(>350^{\circ} \mathrm{C}\right)$, as evidenced by positive $\mathrm{Eu}$ anomalies in carbonates of the about 2.46 to $2.67 \mathrm{Ga}$ Campbellrand Subgroup of the Transvaal Supergroup deposited on the Kaapvaal Craton in South Africa ${ }^{11}$. Evidence for $20-80 \mu \mathrm{M} \mathrm{Fe}$ (II) in the photic zone was previously inferred on the basis of the abundance of herringbone carbonate and the absence of micritic carbonate in the Gamohaan Formation of the Campbellrand Subgroup ${ }^{26,27}$, as Fe(II) acts as an inhibitor to calcite precipitation. In further support of our assertion that upwelling Fe(II) modulated oxygen production, indicators from the sulphur isotope record for oxidation coincident with the GOE (that is, the disappearance of mass independently fractionated sulphur) follow cessation of iron formation deposition associated with sea-level rise from plume-driven volcanism ${ }^{25}$.

Evidence for Archaean atmospheric oxygen now extends as early as $3.0 \mathrm{Ga}$ (refs 1,2 ), and if oxygen production is taken as a smoking gun signalling the initiation of oxygenic photosynthesis on Earth, then the tempo of atmospheric oxidation may reflect not when oxygenic photosynthesis first appeared, but rather shifts in patterns and styles of volcanism across the Archaean-Proterozoic boundary and GOE, such as waning plume-driven volcanism ${ }^{25}$. Coupling the timing of oxygenation to events in secular rather than biological evolution is an old idea recapitulated ${ }^{7}$, with deference to the underlying role that a persistent, local supply of anoxic, $\mathrm{Fe}(\mathrm{II})$ rich sea water could have had on regulating the activity and habitat of one of life's most prolific metabolisms. Central to this proposed series of events is the idea that input and distribution of Fe in the oceans was regulated by the timing and nature of crustal growth. The problem of disposing of oxygen, the toxic waste product of oxygenic photosynthesis, was not solved solely by using the geologic supply of $\mathrm{Fe}(\mathrm{II})$ as a $\operatorname{sink}^{7}$, but it also depended on periods of tectonic quiescence to sustain oxygen production in coastal habitats. More than the role of $\mathrm{Fe}$ as a nutrient ${ }^{9}, \mathrm{Fe}(\mathrm{II})$ toxicity regulates primary productivity in our model. Distinguishing the conditions under which Fe delivery to the oceans either restricted or stimulated primary productivity may well be critical in understanding the redox evolution and major element $(\mathrm{C}, \mathrm{S})$ budgets of Earth's oceans and atmosphere before, during and well after the GOE.

\section{Methods}

Synechococcus PCC 7002 was cultivated on anoxic Marine Phototroph (MP) medium with or without additional $\mathrm{FeCl}_{2}$ at $24^{\circ} \mathrm{C}$ with $12.8 \mu \mathrm{mol}$ photons $\mathrm{m}^{-2} \mathrm{~s}^{-1}$ (ref. 28). The trace element solution provided $7.5 \mu \mathrm{M} \mathrm{Fe}$ (II) to the medium. For growth experiments, $80 \mathrm{ml}$ of medium was poured into $100 \mathrm{ml}$ glass bottles (Schott $\mathrm{AG}$ ) with a headspace of $\mathrm{N}_{2} / \mathrm{CO}_{2}$ (90:10). Growth was monitored by attenuance $\left(D_{750 \mathrm{~nm}}\right)$ measurements for cultures containing $\leq 100 \mu \mathrm{M}$ $\mathrm{Fe}(\mathrm{II})$. For cultures with $>100 \mu \mathrm{M} \mathrm{Fe}(\mathrm{II})$, cells were counted after fixation with paraformaldehyde and dissolution of the $\mathrm{Fe}(\mathrm{III})$ precipitates $^{28}$. Data for the counts in Fig. 1a represent the median value and standard error of counts on individual filters.

Attenuance readings were related to cells $\mathrm{ml}^{-1}$ (Fig. 1a) using a linear relationship determined between $D_{750 \mathrm{~nm}}$ and direct microscopic counts. Growth rates $\left(\mu ; \mathrm{d}^{-1}\right)$ were calculated during exponential growth phase from the linear portion of a semi-log plot of cells $\mathrm{ml}^{-1}(C)$ versus time ( $t$; days) using the equation:

$$
\mu=\left(\ln C_{2}-\ln C_{1}\right) /\left(t_{2}-t_{1}\right)
$$

An unpaired, two-tailed $t$-test (95\% confidence interval) was used to determine whether the difference between a mean value obtained from biological replicates 
performed at one concentration of $\mathrm{Fe}$ (II) was statistically significant from the mean value obtained with $7.5 \mu \mathrm{M}$ or no added Fe(II) (for Fig. 1b-d). These results are reported in Supplementary Table 1. The statistical significance is reported as * for $P<0.05$ (significant), ${ }^{* *}$ for $P<0.01$ (very significant), and ${ }^{* * *}$ for $P<0.001$ (extremely significant). No asterisk indicates that differences are not statistically significant.

For Fe(II) quantification, samples containing $\geq 200 \mu \mathrm{M}$ total Fe were diluted in anoxic $1 \mathrm{~N} \mathrm{HCl}$ and analysed with $0.1 \%$ Ferrozine in $50 \%$ ammonium acetate. Samples containing $\leq 200 \mu \mathrm{M}$ total Fe were reacted directly with Ferrozine for $\mathrm{Fe}(\mathrm{II})$ measurements. Absorption measurements at $563 \mathrm{~nm}$ were made after undiluted samples were centrifuged $(19,000 \mathrm{~g})$ to pellet cells and Fe oxides.

The actinic yield $\left(F_{\mathrm{v}} / F_{\mathrm{m}}\right)$ was determined on log-phase cultures grown at different $\mathrm{Fe}(\mathrm{II})$ concentrations with a Water PAM Chlorophyll Fluorometer (Heinz Walz). Approximately $2 \times 10^{6}$ cells $\mathrm{ml}^{-1}$ were washed and resuspended in a non-growth buffer at $\mathrm{pH} 6.8$ (that is, $\mathrm{MP}$ medium lacking $\mathrm{NH}_{4} \mathrm{Cl}, \mathrm{KH}_{2} \mathrm{PO}_{4}$, $\mathrm{NaHCO}_{3}$, trace elements, vitamin and supplements) for measurement

The membrane-permeable indicator 5-(and-6)-chloromethyl-2', $7^{\prime}$ dichlorodihydrofluorescein diacetate, acetyl ester (CM- $\left.\mathrm{H}_{2} \mathrm{DCFDA}\right)$ from Life Technologies $\mathrm{GmbH}$ was used for detection of intracellular ROS. A log-phase culture was collected by centrifugation and washed two times with a potassium phosphate buffer at $\mathrm{pH}$ 7. Cells were resuspended to a concentration of $2 \times 10^{7}$ cells $\mathrm{ml}^{-1}$ and degassed with $\mathrm{N}_{2} / \mathrm{CO}_{2}(90: 10)$ in the dark. Stocks of anoxic $\mathrm{FeCl}_{2}$ were added to final concentrations of $10 \mu \mathrm{M}, 100 \mu \mathrm{M}$ or $1,000 \mu \mathrm{M}$. The suspensions were incubated, shaking, at $25 \mu \mathrm{mol}$ photons $\mathrm{m}^{-2} \mathrm{~s}^{-1}$ for one hour. Cells were resuspended in fresh buffer with $5 \mu \mathrm{M} \mathrm{CM}-\mathrm{H}_{2} \mathrm{DCFDA}$ and incubated in the dark for $30 \mathrm{~min}$. After resuspension in fresh buffer, the fluorescence emission at $519 \mathrm{~nm}$ (excitation at $490 \pm 5 \mathrm{~nm}$ ) was read using a FluoroMax-4 Spectrofluorometer (Horiba Europe $\mathrm{GmbH}$ ). The fluorescence of non-stained cells and Fe minerals from identical treatments was subtracted.

We developed a steady-state advective-diffusive transport model coupled to the reaction of $\mathrm{Fe}(\mathrm{II})$ with oxygen:

$$
\begin{gathered}
v \frac{\mathrm{d} c_{\mathrm{Ox}}}{\mathrm{d} z}-\frac{\mathrm{d}}{\mathrm{d} z}\left(D \frac{\mathrm{d} c_{\mathrm{Ox}}}{\mathrm{d} z}\right)=r_{\text {photo }}^{\max } \exp \left(-\frac{z}{z_{\text {photo }}}\right)-\gamma c_{\mathrm{Ox}}^{n} c_{\mathrm{Fe}} \\
v \frac{\mathrm{d} c_{\mathrm{Fe}}}{\mathrm{d} z}-\frac{\mathrm{d}}{\mathrm{d} z}\left(D \frac{\mathrm{d} c_{\mathrm{Fe}}}{\mathrm{d} z}\right)=-4 \gamma c_{\mathrm{Ox}}^{n} c_{\mathrm{Fe}}
\end{gathered}
$$

subject to

$$
\begin{gathered}
c_{\mathrm{Ox}}(0)=c_{\mathrm{Ox}, 0} \\
\left.\frac{\mathrm{d} c_{\mathrm{Fe}}}{\mathrm{d} z}\right|_{z=0}=0 \\
\left.\frac{\mathrm{d} c_{\mathrm{Ox}}}{\mathrm{d} z}\right|_{z=z_{\max }}=0 \\
c_{\mathrm{Fe}}\left(z_{\max }\right)=c_{\mathrm{Fe} \text {, max }}
\end{gathered}
$$

in which $c_{\mathrm{Ox}}\left[\mathrm{moll}^{-3}\right]$ and $c_{\mathrm{Fe}}\left[\mathrm{moll}^{-3}\right]$ are the concentrations of dissolved oxygen and $\mathrm{Fe}(\mathrm{II})$, respectively, $z[\mathrm{~m}]$ denotes depth, $v\left[\mathrm{~m} \mathrm{~s}^{-1}\right]$ is the upwelling velocity, $D\left[\mathrm{~m}^{2} \mathrm{~s}^{-1}\right]$ is the depth-dependent eddy diffusion coefficient, $r_{\text {photo }}^{\max }\left[\mathrm{moll}^{-3} \mathrm{~s}^{-1}\right]$ is the maximum photosynthetic oxygen production rate, $z_{\text {photo }}[\mathrm{m}]$ and $z_{\max }[\mathrm{m}]$ denote the penetration depth of light and the maximum depth of the model domain, respectively, $\gamma\left[1^{3 n} \mathrm{~mol}^{-n} \mathrm{~s}^{-1}\right]$ is the pseudo-bimolecular rate coefficient of $\mathrm{Fe}(\mathrm{II})$ oxidation by oxygen, $n[-]$ is the exponent of oxygen in the rate law, and $c_{\mathrm{Ox}, 0}\left[\mathrm{moll}^{-3}\right]$ and $c_{\mathrm{Fe}, \max }\left[\mathrm{moll}^{-3}\right]$ are the fixed concentrations of oxygen and $\mathrm{Fe}(\mathrm{II})$ at the top and bottom of the modelled domain, respectively.

The eddy diffusion coefficient was estimated at each depth on the basis of diffusivities calculated from vertical profiles of the Black Sea ${ }^{29}$ :

$$
D(z)= \begin{cases}1 \times 10^{-5}\left[\mathrm{~m}^{2} \mathrm{~s}^{-1}\right]-1.6 \times 10^{-7}\left[\mathrm{~m} \mathrm{~s}^{-1}\right] \times z & \text { if } z<50[\mathrm{~m}] \\ 4 \times 10^{-8}\left[\mathrm{~m} \mathrm{~s}^{-1}\right] \times z & \text { otherwise }\end{cases}
$$

resulting in $D=2 \times 10^{-6} \mathrm{~m}^{2} \mathrm{~s}^{-1}$ at the pycnocline, assumed at $50 \mathrm{~m}$ depth. The electron transport rate (ETR) was calculated from $F_{\mathrm{v}} / F_{\mathrm{m}}$ :

$$
\mathrm{ETR}=F_{\mathrm{v}} / F_{\mathrm{m}} \times \mathrm{PAR} \times \mathrm{AF} \times 0.5
$$

where PAR is photosynthetically active radiation $\left(\mu \mathrm{mol}\right.$ electrons $\left.\mathrm{m}^{-2} \mathrm{~s}^{-1}\right)$, and $\mathrm{AF}$ is the absorption factor for the fraction of incident PAR absorbed by cells. The 0.5 term indicates that $50 \%$ of absorbed photons are used by Photosystem II. Our $F_{\mathrm{m}} / F_{\mathrm{v}}$ data yield the following inhibition law:

$$
\mathrm{ETR}=\mathrm{ETR}_{\max } \times\left(c+1 \times 10^{-6}\right)^{-n}
$$

where $n=0.107 \pm 0.023$, and using linearized uncertainty propagation. All parameters applied in the model are detailed in Supplementary Table 2.
Received 14 August 2014; accepted 24 November 2014; published online 5 January 2015

\section{References}

1. Planavsky, N. J. et al. Evidence for oxygenic photosynthesis half a billion years before the Great Oxidation Event. Nature Geosci. 7, 283-286 (2014).

2. Crowe, S. A. et al. Atmospheric oxygenation three billion years ago. Nature 501, 535-538 (2013)

3. Bekker, A. et al. Dating the rise of atmospheric oxygen. Nature 427, $117-120$ (2004).

4. Barley, M. E., Pickard, A. L. \& Sylvester, P. J. Emplacement of a large igneous province as a possible cause of banded iron formation 2.45 billion years ago. Nature 385, 55-58 (1997).

5. Kendall, B. et al. Pervasive oxygenation along late Archean ocean margins. Nature Geosci. 3, 647-652 (2010).

6. Shcolnick, S., Summerfield, T. C., Reytman, L., Sherman, L. A. \& Keren, N. The mechanism of iron homeostasis in the unicellular cyanobacterium Synechocystis sp. PCC 6803 and its relationship to oxidative stress. Plant Physiol. 150, 2045-2056 (2009).

7. Cloud, P. E. Jr Atmospheric and hydrospheric evolution on the primitive Earth: Both secular accretion and biological and geochemical processes have affected Earth's volatile envelope. Science 160, 729-736 (1968).

8. Kasting, J. F. What caused the rise of atmospheric $\mathrm{O}_{2}$ ? Chem. Geol. 362, 13-25 (2013).

9. Martin, J. H. Glacial-interglacial $\mathrm{CO}_{2}$ change: The iron hypothesis. Paleoceanography 5, 1-13 (1990).

10. Beukes, N. J. \& Gutzmer, J. Origin and paleoenvironmental significance of major iron formations at the Archean-Paleoproterozoic boundary. SEG Rev. 15, 5-47 (2008).

11. Kamber, B. S. \& Webb, G. E. The geochemistry of late Archaean microbial carbonate: Implications for ocean chemistry and continental erosion history. Geochim. Cosmochim. Acta 65, 2509-2525 (2001).

12. Olson, S. L., Kump, L. R. \& Kasting, J. F. Quantifying the areal extent and dissolved oxygen concentrations of Archean oxygen oases. Chem. Geol. 362, $35-43$ (2013).

13. Field, C. B., Behrenfeld, M. J., Randerson, J. T. \& Falkowski, P. Primary production of the biosphere: Integrating terrestrial and oceanic components. Science 281, 237-240 (1998).

14. Flombaum, P. et al. Present and future global distributions of the marine Cyanobacteria Prochlorococcus and Synechococcus. Proc. Natl Acad. Sci. USA 110, 9824-9829 (2013).

15. Campbell, D., Hurry, V., Clarke, A. K., Gustaffson, P. \& Oquist, G. Chlorophyll fluorescence analysis of cyanobacterial photosynthesis and acclimation. Microbiol. Mol. Biol. Rev. 62, 667-683 (1998).

16. Nishiyama, Y., Allakhverdiev, S. I. \& Murata, N. A new paradigm for the action of reactive oxygen species in the photoinhibition of photosystem II. Biochim. Biophys. Acta 1757, 742-749 (2006).

17. Demirel, S., Ustun, B., Aslim, B. \& Suludere, Z. Toxicity and uptake of iron ions by Synechocystis sp. E35 isolated from Kucukcekmece Lagoon, Istanbul. J. Hazard. Mater. 171, 710-716 (2009).

18. Trabucho Alexandre, J. et al. The mid-Cretaceous North Atlantic nutrient trap Black shales and OAEs. Paleoceanography 25, PA4201 (2010).

19. Anbar, A. D. et al. A whiff of oxygen before the great oxidation event? Science 317, 1903-1906 (2007).

20. Wille, M. et al. Evidence for a gradual rise of oxygen between 2.6 and $2.5 \mathrm{Ga}$ from Mo isotopes and Re-PGE signatures in shales. Geochim. Cosmochim. Acta 71, 2417-2435 (2007).

21. Sumner, D. Y. \& Beukes, N. J. Sequence stratigraphic development of the Neoarchean Transvaal carbonate platform, Kaapvaal, Craton, South Africa. South Afr. J. Geol. 109, 11-22 (2006).

22. Godfrey, L. V. \& Falkowski, P. G. The cycling and redox state of nitrogen in the Archaean ocean. Nature Geosci. 2, 725-729 (2009).

23. Kaufman, A. J. et al. Late Archean biospheric oxygenation and atmospheric evolution. Science 317, 1900-1903 (2007)

24. Czaja, A. D. et al. Evidence for free oxygen in the Neoarchean ocean based on coupled iron-molybdenum isotope fractionation. Geochim. Cosmochim. Acta 86, 118-137 (2012).

25. Barley, M. E., Bekker, A. \& Krapež, B. Late Archean to early Paleoproterozoic global tectonics, environmental change and the rise of atmospheric oxygen. Earth Planet. Sci. Lett. 238, 156-171 (2005).

26. Sumner, D. Y. Carbonate precipitation and oxygen stratification in late Archean seawater as deduced from facies and stratigraphy of the Gamohaan and Frisco formations, Transvaal Supergroup, South Africa. Am. J. Sci. 297, 455-487 (1997).

27. Sumner, D. Y. \& Grotzinger, J. P. Were kinetics of Archean calcium carbonate precipitation related to oxygen concentrations? Geology 24, 119-122 (1996). 
28. Wu, W. et al. Characterization of the physiology and cell-mineral interactions of the marine anoxygenic phototrophic Fe(II)-oxidizer Rhodovulum iodosum-implications for Precambrian Fe(II) oxidation. FEMS Microbiol. Ecol. 88, 503-515 (2014)

29. Lewis, B. L. \& Landing, W. M. The biogeochemistry of manganese and iron in the Black Sea. Deep-Sea Res. A 38 (suppl. 2), S773-S803 (1991).

30. Cockell, C. S., Kelly, L. C., Summers, S. \& Marteinsson, V. Following the kinetics: Iron-oxidizing microbial mats in cold Icelandic volcanic habitats and their rock-associated carbonaceous signature. Astrobiology 11, 679-694 (2011)

31. Hegler, F., Lösekann-Behrens, T., Hanselmann, K., Behrens, S. \& Kappler, A. Influence of seasonal and geochemical changes on the geomicrobiology of an iron carbonate mineral water spring. Appl. Environ. Microbiol. 78, 7185-7196 (2012).

32. Kato, S., Chan, C., Itoh, T. \& Ohkuma, M. Functional gene analysis of freshwater iron-rich flocs at circumneutral $\mathrm{pH}$ and isolation of a stalk-forming microaerophilic iron-oxidizing bacterium. Appl. Environ. Microbiol. 79, 5283-5290 (2013).

33. James, R. E. \& Ferris, F. G. Evidence for microbial-mediated iron oxidation at a neutrophilic groundwater spring. Chem. Geol. 212, 301-311 (2004).

34. Mitsunobu, S. et al. Bacteriogenic Fe(III) (oxyhydr)oxides characterized by synchrotron microprobe coupled with spatially resolved phylogenetic analysis. Environ. Sci. Technol. 46, 3304-3311 (2012).

35. Pierson, B. K., Paranteau, M. N. \& Griffin, B. M. Phototrophs in high-ironconcentration microbial mats: Physiological ecology of phototrophs in an iron-depositing hot spring. Appl. Environ. Microbiol. 65, 5474-5483 (1999).

36. Trouwborst, R. E., Johnston, A., Koch, G., Luther III, G. W. \& Pierson, B. K Biogeochemistry of $\mathrm{Fe}(\mathrm{II})$ oxidation in a photosynthetic microbial mat Implications for Precambrian Fe(II) oxidation. Geochim. Cosmochim. Acta 71 4627-4643 (2007).

37. Gault, A. G. et al. Seasonal changes in mineralogy, geochemistry and microbial community of bacteriogenic iron oxides (BIOS) deposited in a circumneutral wetland. Geomicrobiol. J. 29, 161-172 (2011).

38. Duckworth, O. W., Holmstrm, S. J. M., Pea, J. \& Sposito, G. Biogeochemistry of iron oxidation in a circumneutral freshwater habitat. Chem. Geol. 260 , 149-158 (2009).
39. Rentz, J. A., Kraiya, C., Luther, G. W. \& Emerson, D. Control of ferrous iron oxidation within circumneutral iron mats by cellular activity and autocatalysis. Environ. Sci. Technol. 41, 6084-6089 (2007).

40. Druschel, G. K., Emerson, D., Sutka, R., Suchecki, P. \& Luther III, G. W. Low-oxygen and chemical kinetic constraints on the geochemical niche of neutrophilic iron(II) oxidizing microorganisms. Geochim. Cosmochim. Acta 72, 3358-3370 (2008)

41. Emerson, D. \& Revsbech, N. P. Investigation of an iron-oxidizing microbial mat community located near Aarhus, Denmark: Field studies. Appl. Environ Microbiol. 60, 4022-4031 (1994).

42. Roden, E. et al. The microbial ferrous wheel in a neutral $\mathrm{pH}$ groundwater seep. Frontiers in Microbiology 3 (2012).

\section{Acknowledgements}

This work was supported by an NSF IRFP fellowship to E.D.S. Synechococcus PCC 7002 was a gift from M. Eisenhut. D. Deubel, V. Hof, A. Klotz, E. Koeksoy, M. Maisch, S. Schmidt, C. Vogt and W. Wu assisted with experiments. This project benefited from helpful discussion with S. Eroglu, K. Forchhammer, S. J. Mojzsis, M. Mühe, M. Obst, A. Picard and B. Voelker.

\section{Author contributions}

E.D.S., O.A.C. and A.K. designed the research; E.D.S. performed the research, E.D.S., O.A.C. and A.K. analysed the data; R.S., A.M.M. and K.O.K. helped to develop key themes; E.D.S. wrote the paper, with major contributions from A.K., A.M.M., R.S and K.O.K.

\section{Additional information}

Supplementary information is available in the online version of the paper. Reprints and permissions information is available online at www.nature.com/reprints.

Correspondence and requests for materials should be addressed to E.D.S.

\section{Competing financial interests}

The authors declare no competing financial interests. 